\title{
Small entrepreneurship as factor of sustainable development of region's economy under environmental restrictions
}

\author{
Burov V. Y. \\ Department of Economic Theory and World Economy \\ Transbaikal State University \\ Chita, Russia \\ e-mail: burovschool@rambler.ru
}

Seliverstov P.V.

Department of Clinical Diagnosis and Minimally Invasive Surgery of the Scientific Department of Clinical Surgery Irkutsk Scientific Center of Surgery and Traumatology Irkutsk, Russia e-mail: pavv2001@gmail.com

\begin{abstract}
The article concerns the problem of ensuring of sustainable development of the region's economy under environmental restrictions. The recession of the levels of functional capabilities of the formation of various management systems in the aspect of the impact of technogenic factors on man's organism is shown. The role of small entrepreneurship in raising the level of social and economic development of the region was/is noted. It was revealed that under environmental restrictions, small enterprises are forced to reorient their activities to the shadow sector of the economy, which also leads to economic crimes. The level of implementation of environmental innovations, as one of the methods for ensuring environmental safety, is illustrated by the example of the Siberian Federal District regions using official statistics. The necessity of increasing innovative developments in the field of environmental protection and their financing is substantiated.
\end{abstract}

Keywords-sustainable development; environmental restrictions; small entrepreneurship; economic security; environmental innovations

\section{INTRODUCTION}

In modern conditions of increased instability and aggressiveness of the external environment, which is predetermined by economic sanctions from the European Economic Union and the United States of America, the problem of ensuring sustainable development of small entrepreneurship as a factor of growth of regional economies is relevant. It is directly related to small entrepreneurship competitiveness.

And this is consistent with the position of Russian scientists. Thus, V. V. Matveyev considered that «Small enterprises contribute to the democratization of market relations, the formation of a competitive environment ... attach

\author{
Vladimirova O.N \\ Department of Accounting, Analysis and Audit \\ Siberian Federal University \\ Krasnoyarsk, Russia \\ e-mail:olga.ovladimirova24@yandex.ru
}

\author{
Kaibalina N. B. \\ «Taseevskoe» LLC \\ Chita, Russia \\ e-mail: natalia.kaybalina@taseevskoye.ru
}

the housekeeper properties of adaptability and flexibility» [6]. And, according to Y. S. Pinkovetskaya «The crisis in the Russian economy can be overcome due to the transformation of its structure on the basis of increasing the role of small and medium entrepreneurship» [7].

The competitiveness of the regions' economy is largely determined by the existing restrictions on the conduct of economic activities. Among them, the authors will consider ecological restrictions, which are connected with the establishment of special rules for doing business in the territory.

The impact of this factor is expressed in additional expenses, losses and lost profit of the entities of small businesses, particularly, the region's economy as a whole. Therefore, for increasing competitiveness of the sector of small entrepreneurship, the region with environmental restrictions is required to use specific organizational schemes and mechanisms of economy management for the purpose of sustainable development.

At the same time, it should be emphasized that virtually every subject of Russia has territories where environmental restrictions apply. And from here, there is a problem of how to link the sustainable development of the territories' economies, environmental constraints and, at the same time, the development of innovative technologies arises.

The relevance of the chosen topic is confirmed by the fact that small enterprises are characterized by high flexibility, innovation, which is especially important under conditions of reorienting the economy to an innovative development path

\section{RESULTS AND DISCUSSION}

The sustainable development of the regions largely 
depends on the entrepreneurial climate - the more favorable it is, the higher the final economic result of the activity is. External factors, which are affecting the entrepreneurial climate, are associated with the elements of regional and institutional environments. And one can note the existing environmental restrictions among them.

At the same time, the regions' economy and especially municipalities largely depends on the sustainable development of small entrepreneurship. It is directly related to the negative factors affected small entrepreneurship development. Among them, according to S. A. Ivanov, there are: the imperfection of the tax system; instability and imperfection of the regulatory and legal framework; administrative barriers; lack of reliable social protection and security of businesspeople; underdevelopment of the mechanisms of financial and credit support and of the insurance of risks of small enterprises; limited access of small enterprises to the production facilities, property; inefficient mechanisms; instability of budget financing of federal and regional programs to support small entrepreneurship and other factors [4].

Fully agreeing with this, the authors consider that the introduction of economic activities in the areas with environmental restrictions should be recognized as an additional negative factor for the environment. Environmental restrictions are special conditions (regulation) of using natural resources and their protection from negative (harmful) influences, which are regulated by a set of regulatory and legal measures prevented the destruction of ecosystems.

Analysis of the development trends of the modern Russian entrepreneurship allows us to reveal that one of the main trends is the shadow economic action, which is characterized by its consistency and penetration in all sectors of economy and spheres of society. Herewith, the regularity of the shadow economic relations is justified by the essence of entrepreneurial activity, which is risky and has making a profit as its main goal.

Studies confirm that the ineffectiveness of state support for small entrepreneurship is manifested by its small contribution to the country's gross domestic product, which is about $20 \%$ versus $50-70 \%$ in countries with developed economy (USA, Japan, UK and others). Wherein the number of small enterprises in 2010-2015 per 1000 inhabitants in Russia is 6-7, while abroad - 25-30. In most developed countries, small business creates about $80 \%$ of workspaces, in Russia - about $20 \%$.

The existing situation (ineffectiveness of state support of small entrepreneurship and its shadow economic activities) negatively affects the level of competitiveness of small enterprises. And the competitiveness of small business representatives under these conditions is not achieved due to equal conditions of activity, but due to corrupt relations that leads to the appearance of imperfect competition - supply and demand for goods and services are defined not by the market, but by the corruption mechanism.

The role of small entrepreneurship in the sustainable development of the region's economy is seen by its authors in its ability to develop and retain competitive advantages and improve its position in the structure of the region's economy by creating products that are more attractive for consumers in terms of price and non-price characteristics. Wherein using its potential, the innovative nature of its activities, the ability to respond quickly to changes in the socioeconomic and organizational factors of the external entrepreneurial environment.

In the period of unstable development of the territories one of the ways to increase the contribution of small businesses to the economy of the region is the development of tourism, which is a priority sector for many regions. So the Irkutsk region and the Republic of Buryatia, on the territory of which Lake Baikal is located - a world heritage, according to monitoring, in 2015, visited more than 2.5 million people. Moreover, the main stream of tourists observed on the shore of Lake Baikal.

It requires the creation of adequate conditions for development of small tourism entrepreneurship, but, at the same time local authorities make high demands on nature conservation and providing environmental safety - the protection mode of Lake Baikal is set by the federal law (1999) dated from 01.05.1999, № 94 «On Protection of Lake Baikal».

According to B. N. Porfiriev: "It is connected primarily with growing threats to the environment, first of all - the sustainability of ecosystems, which provide conditions and resources for the reproduction of material goods and for human vital activity" [8].

Economic activity of small enterprises under the conditions of environmental restrictions should be focused on providing environmental safety, which, according to A. A. Smagulov \& Karajanov, «is a component of the security of a state, a society and a particular person. Within its framework, demands to variety human activities are made, restrictions and prohibitions are set» [10].

The lack of opportunity for small enterprises to compete under environmental restrictions forces them to go on breaking laws. It leads to economic crimes in this area. As the author noted earlier: «The prevention of economic criminality should be based on the well-timed detection and neutralization of its causes and conditions and should be considered as one of the most important direction of preventive work of public (law enforcement and supervisory) authorities and non-state security structures» [3]. This is especially true for the extraction of fish resources, and for logging and wood processing. Taking into account the Baikal factor, the borders of the Baikal natural territory were legislatively established and a ban on industrial logging in the central ecological zone was introduced.

According to A. P. Anisimov, economic reasons of the environmental crime lie in the fact that the mechanism of economic regulation of environmental protection, which was adopted in Russia, works very poorly. Also, it does not allow the use of technologies based on the latest achievements of science and technology aimed at reducing the negative impact on the environment and having a set period of practical application, taking into account economic and social factors 
[1].

In terms of social factors, it is possible to note the relationship of a person with the environment, which nowadays acquires practical relevance. In the system of social values, human health occupies an increasingly important place. It determines the quality of life with the performance of labor activity with the maximum duration of active life, the preservation of the genetic material of reproductive cells with the reproduction of full-fledged offspring with the preservation and development of the health of modern and future generations.

In the regions of Siberia, aluminum production is highly developed. In the process of its production, aluminum oxides and its fluoride compounds are emitted into the atmosphere. The toxic effect of fluoride compounds is most harmful when entering the bio-organism by inhalation, but in addition to their intake with water, the act of toxins on the human body is intensified.

Sanitary and hygienic studies of territories with an analysis of the dynamics of atmospheric air pollution and levels of morbidity in the population living in hygienically unfavorable regions reveal that the severity of the manifestation of various pathologies is proportional to the length of residence in these zones. In the technogenically-unpolluted region, this dependence is not found.

The influence of anthropogenic pollution on the incidence of the population of industrial centers is confirmed by data published in the annual state reports of the Main Directorate of Natural Resources and Environmental Protection of the Ministry of Natural Resources of Russia for the Irkutsk region. In 2015, it was noted that the level of diseases of the musculoskeletal system from 2010-2015 increased to $49.4 \%$ as compared with the period 2000-2010 - 33\%.

Obtained data clearly show a decrease in the levels of functional capabilities of the formation of various management systems in the context of using labor resources under conditions of the impact on their organism of technogenic factors, which directly affects the competitiveness of the territories.

A special branch where the "tandem" is clearly manifested: ecological restrictions - economic crime, is the forest industry. As an example, it is possible to cite the fact that in Buryatia and Irkutsk region, clear-cutting is limited, volumes of environmentally justified cuttings of intermediate use have increased; environment-friendly machinery and harvesting technology are introduced. That has led to an increase of the costs of harvesting and processing of timber and, accordingly, an increase of the incidence of illegal logging. It has given a rise to the phenomenon of "black lumberjacks". According to expert surveys and empirical researches, the shadow economic activity in the forestry sector among small enterprises and informal physical communities reach not less than $50 \%$ of the general volume.

Only in Irkutsk region in 2012, the damage from illegal timber harvesting amounted 1.2 billion rouble, while the volume of illegally harvested timber achieved $254.221 \mathrm{~m}^{3}$ only in one year [9]. And here one should agree that «environmental safety is exposed increasingly to risks in connection with the activity of organized forms of crime in the area of illegal logging, which exist under the guise of law enforcement agencies and the authorities» [5].

On the one hand, in carrying out its economic activities under environmental restrictions, the dual role of small enterprises in ensuring their own economic security is noted. On the other hand, promoting the economically safe functioning of regional-economic systems is noted too.

Innovation plays an important role in ensuring the environmental safety of regions and the country. Environmental innovations are innovations implemented in the framework of technological, organizational or marketing innovations and aimed at improving environmental safety both in the production process and as a result of the use of innovative products.

The need for more active application of innovative activities in this area is conditioned by two groups of factors: firstly, by climate, and, secondly, by the practice of implementing protective environmental measures in the economic activities of economic entities.

The climate of Russia is sharply continental in most of its territory: it is distinguished by a large amplitude of seasonal temperature changes from hot summer to very cold winter. Climate warming over the past decades is a worldwide trend, which change associated with anthropogenic emissions of greenhouse gases. Despite the measures taken within the framework of the United Nations Framework Convention on Climate Change to limit greenhouse gas emissions, the growth of their concentration continues. The concentration of carbon dioxide according to the data of Russian and foreign background Arctic stations is growing at the current rate of about 2 million $^{-1}$ per year (at the end of the 20th century it was 1.5 million $^{-1} /$ year) and reached its next maximum in 2015: about 402 million $^{-1}$. Methane concentration increases. The rate of modern growth in global temperature was in 1976 - 2015 about $0,17^{\circ} \mathrm{C}$ for 10 years (estimate according to the Hadley Center of the Meteorological Service of Great Britain). The temperature in Russia is growing much faster: $0,45^{\circ} \mathrm{C}$ in 10 years, and especially rapidly in the polar region, where the growth rate reaches $0,8^{\circ} \mathrm{C}$ in 10 years. Therefore, the need for innovation is an objective necessity in Russia.

The second group of factors reflects the general ecological culture of management. Strategies of economic activity of many enterprises aimed at obtaining the highest possible level of profit without taking into account the environmental impact for most of them - are priority. At the same time, the official statistics data show a fairly high proportion of enterprises implementing innovations that ensure an increase in environmental safety in the production of goods, works, services: according to the Russian Federation (Table 1), depending on the direction of the activity, the range is from $40,5 \%$ to $81.2 \%$. 
TABLE I. ORGANIZATIONS IMPLEMENTED INNOVATIONS WHICH IMPROVED ENVIRONMENTAL SAFETY IN THE PRODUCTION OF GOODS, WORKS, SERVICES (AS A PERCENTAGE OF THE TOTAL NUMBER OF ORGANIZATIONS IMPLEMENTED ENVIRONMENTAL INNOVATIONS OF THE RELEVANT SUBJECT OF THE RUSSIAN FEDERATION)

\begin{tabular}{|c|c|c|c|c|c|c|c|c|c|c|c|c|}
\hline & \multicolumn{2}{|c|}{\begin{tabular}{|c|} 
Reduction of \\
material costs for the \\
production of a unit \\
of goods, works, \\
services
\end{tabular}} & \multicolumn{2}{|c|}{\begin{tabular}{|} 
Reduction of energy \\
costs for the \\
production of a unit \\
of goods, works, \\
services
\end{tabular}} & \multicolumn{2}{|c|}{\begin{tabular}{|c} 
Reducing the \\
release of carbon \\
dioxide $\left(\mathrm{CO}_{2}\right)$ into \\
the atmosphere
\end{tabular}} & \multicolumn{2}{|c|}{$\begin{array}{c}\text { Replacement of } \\
\text { crude materials } \\
\text { and materials with } \\
\text { less dangerous ones }\end{array}$} & \multicolumn{2}{|c|}{\begin{tabular}{|c|} 
Reduction of \\
environmental \\
pollution (air, land \\
and water resources, \\
noise reduction)
\end{tabular}} & \multicolumn{2}{|c|}{$\begin{array}{c}\text { Recycling of waste } \\
\text { production, water or } \\
\text { materials }\end{array}$} \\
\hline & 2014 & 2015 & 2014 & 2015 & 2014 & 2015 & 2014 & 2015 & 2014 & 2015 & 2014 & 2015 \\
\hline The Russian Federation & 50.1 & 45.3 & 55.4 & 55.8 & 41.8 & 43.0 & 45.0 & 40.5 & 81.2 & 79.8 & 45.6 & 46.5 \\
\hline Siberian Federal District & 51.3 & 47.3 & 53.9 & 54.1 & 34.2 & 40.5 & 42.1 & 36.5 & 81.6 & 71.6 & 46.1 & 39.2 \\
\hline The Altai Republic & 50.0 & 100 & 100 & - & 100 & 100 & 50.0 & 100 & 100 & 100 & 50.0 & - \\
\hline $\begin{array}{c}\text { The Republic of } \\
\text { Buryatia }\end{array}$ & - & - & - & - & 50.0 & 100 & - & - & 100 & 100 & - & - \\
\hline $\begin{array}{c}\text { The Republic of } \\
\text { Khakassia }\end{array}$ & - & - & - & - & - & - & 100 & 100 & 100 & 100 & - & - \\
\hline Altai region & 75.0 & 72.7 & 91.7 & 54.5 & 41.7 & 45.5 & 41.7 & 36.4 & 91.7 & 81.8 & 50.0 & 45.5 \\
\hline Transbaikal region & 33.3 & 50.0 & 33.3 & 50.0 & 33.3 & 50.0 & 66.7 & 100 & 66.7 & 50.0 & - & - \\
\hline Krasnoyarsk region & 43.8 & 23.1 & 43.8 & 46.2 & 31.3 & 30.8 & 37.5 & 15.4 & 100 & 76.9 & 56.3 & 38.5 \\
\hline Irkutsk region & 41.7 & 40.0 & 33.3 & 50.0 & 25.0 & 40.0 & 25.0 & 10.0 & 66.7 & 60.0 & 41.7 & 30.0 \\
\hline Kemerovo region & 28.6 & 40.0 & 28.6 & 80.0 & - & - & 42.9 & 40.0 & 57.1 & 80.0 & 28.6 & 40.0 \\
\hline Novosibirsk region & 71.4 & 46.7 & 71.4 & 60.0 & 42.9 & 46.7 & 57.1 & 46.7 & 71.4 & 60.0 & 71.4 & 33.3 \\
\hline Omsk Region & 62.5 & 50.0 & 62.5 & 66.7 & 37.5 & 50.0 & 50.0 & 50.0 & 75.0 & 83.3 & 37.5 & 50.0 \\
\hline Tomsk region & 66.7 & 66.7 & 66.7 & 55.6 & 50.0 & 44.4 & 50.0 & 44.4 & 83.3 & 66.7 & 66.7 & 66.7 \\
\hline
\end{tabular}

In the regional context, there are large gaps, ranging from total absence (for example, in the Siberian Federal District there is no such format of organizations in the Republics of Buryatia and Khakassia) to $100 \%$ (the Republic of Altai). In the subjects of the Federation, characterized by industrial specialization, the priority types of environmental innovations are innovations aimed at reducing environmental pollution (air, land and water resources, noise reduction $(60-100 \%$ of enterprises), the recycling of production waste, water or materials (30-66.7\%), replacement of crude materials and materials with less dangerous substances (15.7-100\%), a reduction of carbon dioxide $\left(\mathrm{CO}_{2}\right)$ emissions (30-100\%), etc.

The use of obsolete technologies in the practice of management, the high share of depreciation of fixed assets predetermine the impossibility of compliance with world standards of environmental safety requirements and cause the need to increase special costs, associated with environmental innovations (the average amount per one organization in 2013 was 49500 rub., in 2014 - 75200 rub., in 2015 - 84500 rub).

The authors have illustrated the foregoing by the example of one of the largest regions of the Russian Federation - the Krasnoyarsk Territory. Its uniqueness lies in significant spatial characteristics: the area is $13,86 \%$ of the country's territory and is located in three climatic zones - arctic, subarctic and temperate.

The major contribution to environmental pollution in the region is made by large-scale industry: 17 cities of the province produce $76.6 \%$ of harmful emissions and annually, up to 12.0 million tons of pollutants belong to industrial aerosols and gases.
In the Krasnoyarsk Territory, a relatively small proportion of organizations implemented environmental innovations in the total number of organizations - the range of values is $1.3 \%$ $-5.1 \%$ (Table 2).

TABLE II. GENERAL ECONOMIC INDICATORS OF ORGANIZATIONS IMPLEMENTED ENVIRONMENTAL INNOVATIONS

\begin{tabular}{|l|r|r|r|r|r|}
\hline & 2011 & 2012 & 2013 & 2014 & 2015 \\
\hline $\begin{array}{l}\text { Specific gravity of organizations } \\
\text { carried out environmental } \\
\text { innovations in the total number of } \\
\text { organizations, percent }\end{array}$ & 5.1 & 1.4 & 1.5 & 1.6 & 1.3 \\
\hline $\begin{array}{l}\text { Number of organizations using the } \\
\text { pollution control system, units }\end{array}$ & 92 & 100 & 108 & 104 & 118 \\
\hline $\begin{array}{l}\text { The amount of special costs } \\
\text { associated with environmental } \\
\text { innovation, million rubles }\end{array}$ & 368.0 & 363.1 & 281.4 & 546.6 & 421.9 \\
\hline
\end{tabular}

In dynamics, there is a downward trend, beginning with a sharp contraction in 2012. There is an increase in the number of organizations using the system for monitoring environmental pollution, compared to 2011 - by $28 \%$. In general, the amounts of special expenses of economic entities, associated with environmental innovations, have remained at an insufficiently high level throughout the period which is under review. 
The given data testify to the need for attention to the issues of innovative processes activation in the sphere of ecology. It should be reflected in the strengthening of environmental legislation, and also have a more dense correlation with the provisions of tax and financial legislation as an incentive and increase motivation of economic entities. The most important area of activity is also the increase of innovative receptivity of the regions in general [2].

\section{METHODS OF RESEARCH}

In the process of research, modern methods of scientific cognition of economic processes were used: a systematic approach when studying the problems of economic activity of small enterprises; a logical approach - when developing factors of impact indicators, indicators of development of competitiveness of small entrepreneurship in the region; an economic and statistical approach - when analyzing and assessing the level of development of small entrepreneurship in the region and the scale of its shadow economic activities; an approach of economic-mathematical modeling - when assessing the factor influence on the development of small entrepreneurship; an expert approach - when assessing the main negative factors that destabilize the formation and development of small entrepreneurship.

The reliability of the research results is provided by the use of modern methods of collecting and processing the initial information, as well as a large array of official statistics.

\section{CONCLUSIONS}

Researches show that a new reasonable system of effective management of sustainable development of the territory is required at the regional level under the conditions of the environmental restrictions and reorientation of the business entities' activities to the innovative development path. And the foundation should include a concept of the regulatory influence of the state, which is aimed at minimizing the economic and environmental crime and creating economic and legal conditions for innovation in order to provide national, economic and environmental security.

Given statistical data both on the whole in the country and in the detailed section show that there is an influence of the sectoral regional specialization in the implementation of environmental innovations by business entities. The level of special costs associated with environmental innovations demonstrates the need to provide government support to the entities of small business.

A promising direction of increasing the competitiveness of the areas through the development mechanism is to develop innovative technologies of environmental conservation that provide the creation of innovative productions on the base of using non-traditional crude materials and the introduction of closed cycles of technological processing for the forest industry.

This confirms the urgency of the need to create an adequate economic and legal environment for the small enterprises activities in these business conditions. It provides certain preferences in the field of taxation, as well as increasing the level of social security and business security, the introduction of developed mechanisms for financial and credit support and risk insurance for small enterprises, reducing restrictions on access of small enterprises to production facilities and property.

\section{References}

[1] A.P. Anisimov, A.I. Melikhov, «Actual problems of countering environmental crime in Russia», Criminology Journal of Baikal National University of Economics and Law, vol. 3, pp. 80-89, 2013.

[2] G. Y. Belyakova, A.T. Petrova, A.S. Shchitnikov, O. N. Vladimirova, «Methodical Approaches to the Assessment of Innovative Region Susceptibility», Mediterranean Journal of Social Sciences, vol. 3, pp. 37 44,2015

[3] V.Yu. Burov, N.I. Atanov, V.N. Andrijanov, T.M. Sudakova, «Shadow economy and corruption as a form of economic crime», Criminology Journal of Baikal National University of Economics and Law, vol. 4, pp. 65-74, 2014

[4] S. A. Ivanov, System Management environmental factors as a basis for the sustainable development of small business, Saint Petersburg: Publishing house of the Saint Petersburg State University of Economics and Finance, 2000

[5] I.V. Lavygina, «Organized forms of illegal logging of forest plantations», Criminology Journal of Baikal National University of Economics and Law, vol. 3, pp. 135-142, 2013

[6] V.V. Matveev, A.V. Ovchinnikova, «Evaluation the impact of small enterprises on the development of the national economy in the context of the paradigm "structure-behavior-result"», Bulletin of St. Petersburg State University, vol. 3, pp. 4-26. 2015

[7] U.S. Pinkovetskaya, «Small entrepreneurship in the Ulyanovsk region», Bulletin of the University of Finance, vol. 6, pp. 54-61, 2015.

[8] B.N. Porfiriev A «"green" factor of innovative modernization of the economy: a challenge for Russia», Bulletin of Moscow University, vol. 3, pp. 3-14, 2016

[9] Report of the head of the Forestry Agency of Irkutsk Region V. Akberdi http://www.Interfax-russia.ru.

[10] A.A. Smagulov, M.D. Karajanov, «Problems of combating environmental crime», Criminology Journal of Baikal National University of Economics and Law, vol. 2, pp. 119-125, 2013. 